\title{
Editorial:
}

\section{Wherefore customer loyalty?}

One of the most interesting business experiences over the last ten or so years has been to see how retail financial services and banking in particular have developed in terms of attempting to understand consumers, what they want and how to market effectively to them. From one of the most traditional of retail industries, banking has grown into one driven by technology and, finally, at the beginning of the 21 st century one that is really trying to understand the need to conceptualise consumer behaviour appropriately. This metamorphosis has at least partly been as a result of the new market entrants such as Virgin, and traditional retailers such as Marks \& Spencer and Tesco, venturing into the financial services arena. It is also due to the development of both consumerbased interactive technology, primarily the Internet, and improved database technology for the banks.

Whereas previous generations of bankers took customer loyalty as a given, the new generation of banks know that lifelong customers are a thing of the past and that customers can and will change their bank if their expectations are not met by their existing provider. The increase in competition described above has done a lot for financial services. Virgin's approach of 'identify a genuine customer need, design products to meet that need' was hardly rocket science but it brought with it a desire to focus on the customer and ensure that what was said was clear and uncomplicated, ${ }^{1}$ and many of the multichannel entrants that came into the market followed the Virgin lead in the information provided and manner with which they communicated to customers.
While the language may have become easier to understand, the nature of the relationships banks have with their customers today are, if anything, more complex than ever before. The Internet has changed how people seek information and how quickly and effectively they can compare competing offers. The traditional approach to service is no longer adequate or necessarily appropriate, and the task to deliver equally high levels of service across channels is a particularly difficult one to manage effectively. The adoption of customer relationship management (CRM) in banking has been very much in line with the general shift from a transactionbased model to a relationship-based one with the focus being on the acquisition, development and retention of profitable relationships. Customers can no longer be taken for granted in an interactive, computer literate world. So while the customer has become a more sophisticated, value-driven user, the bank has available to it innovative technologies to ensure that attrition rates are limited. Valued customers require truly personalised services and this means knowing what customers want and do not want and then ensuring that they get it.

In this edition of the Journal Sally Dibb highlights the focus on the customer relationship where, through customer interactions, businesses can identify the potential value of customers resulting in a potential shift to measuring success by share of customer rather than market share. If share of customer becomes the important focus then the organisation must seriously consider individual customer value in terms of the profitability of the 
relationship over time. As Dibb points out, the rewards for increasing retention can be exponentially high for a company like MBNA.

One of the most interesting and potentially rewarding areas to study here is really to understand what a customer's behaviour might mean for a bank. As John Kish $(2000)^{2}$ recently pointed out customers rarely tell the bank manager in advance what they have decided to do and especially when they decide to leave their existing bank for a competitor.

Behavioural-triggering technology can help a bank recognise stages of customer dissatisfaction by alerting the bank to customers who are exhibiting at-risk behaviour. By recognising the signs, the banks have the opportunity to address the customers' concerns and win back their confidence. As Kish has also noted, few banks track and interpret customer inactivity because they have not realised that declining activity is the most reliable measure of customer dissatisfaction. Simply by staying up-to-date with customers whose activity levels have fallen, banks can identify declining loyalty and do something about it. Obviously the specific response has to be in line with the customer's potential lifetime value; a number of tactics are available for this from direct mail to e-mail to a telephone call. Most importantly it offers banks an opportunity to talk to disaffected customers before they leave. It is important for banks to remember that people evolve and change over time and many of these changes are good for the bank. If banks track the rich set of transactions available to them then this information in turn gives them an historical context for understanding customers' current behaviour. A bank that learns to interact with customers in response to customer behaviour is going to build a truly 'learning relationship'.

The reverse side of the learning relationship is that brought about by the increased competition in this industry, everybody else wants your customers and will fight for them. Direct channel banks in particular have good customer retention but have to acquire new customers so that they can grow their business. The conundrum presented by Alison Fisher in this edition is that while the majority of customers state they are satisfied, attrition rates can be anything between 20 and 30 per cent. It is, in other words, one thing to chart and understand the behaviour of existing customers, to interact with them and present appropriate offers, but the competition is always out there with attractive offers to win over previously loyal consumers. While the so-called 'Seducible' customer may be easily attracted to a better offer, the 'Contenteds' are also potential prey in this particular battle.

So what will happen? It is notoriously difficult to crystal ball gaze in the financial services sector, but learning to understand the nature of customer behaviour is perhaps at the root of envisaging the future. The multiple retailers can be taken as a template, or at least an example for conceptualising customer loyalty. They too understood the importance of building share of customer; people can only shop for groceries so much so whom they shop from on a regular basis becomes crucial for the supplier. Loyalty cards provided an incentive to customers and actionable data to the retailers. Six years on since Tesco launched its Clubcard, loyalty is not what it used to be. The fact that most customers tend to have more than one card contradicts the whole notion of loyalty. The problem is simply put: every organisation wants to have a relationship with the customer, hence more loyalty cards are available; more loyalty cards mean less loyalty. The irony of the loyalty card was well put in a letter to The Times: 'Sir, I have accumulated nine loyalty cards 
from various stores and supermarkets, does this make me more loyal or less? 3

While Alison Fisher's acquisition index shows less similarity between the direct channel banks and traditional banks than perhaps one would see between competing multiple retailers, the issue is basically the same: the more players there are out there, the more the battle to win and maintain customers will continue. However close technology brings banks to understanding and talking directly to their customers, their competitors can do the same. Maybe the customers should be the winners in this particular battle, but when one filters in costs to the equation, the result may not be so positive for all but the most profitable of customers. Finally, at the time of writing, the editors note that regulators are putting the finishing touches to plans to enable consumers to move current accounts to a new bank within five days or be able to claim compensation from their existing account holder, ${ }^{4}$ and estimates that this could lead to a trebling in the number of people moving their current accounts. Now this is a real challenge in winning the customer loyalty war.

\section{Isabelle Szmigin and} Marylyn Carrigan Guest Editors

\section{References}

1 Bridgewater, Susan (2001) 'Virgin Direct 2000: Market-Oriented Personal Financial Services', in Jobber, D. (2001) 'Principles and Practice of Marketing' (3rd edn), McGraw-Hill, Maidenhead, UK.

2 Kish, J. (2000) 'Before Your Customers Leave', Bank Marketing, December, Vol. 32, No. 2, p. 30.

3 Burscough, Dr J. (1998), The Times.

4 Winnett, R., and Toyne, S. (2001) 'Switching accounts to be made easier', Sunday Times, Money, p. 1. 